\title{
ЉУБОВНАТА ТЕМАТИКА ВО РОМАНИТЕ ЛУЃЕ И НЕЛУЃЕ НА ЕЛИО ВИТОРИНИ И ПРИВАТНОТО ПРАШАЬЕ НА БЕПЕ ФЕНОЉО
}

\author{
Љиљана Узуновиќ \\ Универзитет „Св. Кирил и Методиј“, Скопје \\ ljiljauz@yahoo.com
}

Целта на текстот е да направи споредба меѓу два воени романа, Луг̇e и нелуѓe на Виторини и Привайнойо йрашање на Фенољо во врска со љубовниот мотив, присутен во двата романа, како и неговата улога во наведените дела. Нивното споредбено читање доведе до издвојување на неколку заеднички точки: во двете дела постојат недвосмислени автобиографски елементи, како и заедничкиот модел препознатлив во романот За кого бијай камбанийе на Хемингвеј. Забележливо е „отсуството“ на протагонистите на романите, присутни бегло или само во сеќавањата. И покрај тоа, утврдивме дека женските ликови - носителки на љубовниот мотив, се многу важен елемент во двете дела: тие се симболи на надежта, па и на самото постоење. Резултатите од нашата споредбена анализа покажаа дека заедничката црта на двата романа е неможноста на протагонистите да си го најдат патот кон иднината. Поразот на љубовен план им ја одзема потребната надеж и двајцата главни јунаци извршуваат, секој на свој начин, „самоубиство со помош на непријателот“. Од овие причини заклучивме дека љубовниот мотив не е спореден, ниту „украсен“ елемент во овие воени романи, туку е вткаен во самата структура на делата, како главен двигател (вистински или како изговор) на дејствата на протагонистите, како и причина за нивната смрт.

Клучни зборови: љубовен мотив, книжевна љубов, автобиографија, секс, надеж, самоубиство, смрт, потрага 


\title{
THE LOVE THEME IN THE NOVELS MEN OR NOT MEN BY ELIO VITTORINI AND A PRIVATE MATTER BY BEPPE FENOGLIO
}

\author{
Ljiljana Uzunoviḱ \\ Ss. Cyril and Methodius University in Skopje \\ ljiljauz@yahoo.com
}

The aim of this paper is comparative analysis of two wartime novels: Men or Not Men by Elio Vittorini and A private matter by Beppe Fenoglio, based on the love theme. The comparative analysis showed that there are few points that are common for both novels: the autobiographical elements, and the common inspiration model - Hemingway's novel For Whom the Bell Tolls. The "absence" of the female protagonists is notable in both novels, namely they are superficially represented or are present only in the memories. However, we asserted that they are very important figures in the novels: they are symbols of hope and of life itself. The analysis also revealed another common characteristic: what persists in regard to the male protagonists is the impossibility that they would find their path to a future life. Their love defeat deprives them of the necessary hope and both protagonists commit "suicide" with the help of the enemy. Thus, we concluded that the love motive is neither secondary nor does it have a mere "decorative" function in this novels, but is rather interwoven in their structure as an impetus of the protagonists' action or as a motive for their death.

Keywords: love motive, literary love, autobiography, physical intimacy, hope, suicide, death, quest 


\section{1 Воведни белешки}

Идејата за овој текст настана во текот на истражувањето што за потребите на докторската дисертација ${ }^{1}$ го правевме во врска со воената тематика во овие (и во други) романи. Тогаш забележавме дека и во двата романа љубовната тематика е особено присутна, иако речиси незабележана од страна на критиката. Во врска со романот Луг̈́ и нелуг̇e на Виторини, оваа тематика ја забележал и, со некои претерувања, ја преточил во текст италијанскиот поет Џакомо Новента, додека во однос на романот Привайнойо йрашање на Бепе Фенољо, критиката оцените за романот главно ги базирала врз „усогласеноста“ меѓу воениот и љубовниот мотив и врз идеолошката припадност на критичарот.

\section{2 Луѓе и нелуѓe}

Романот Луѓe и нелуѓe бил пишуван од пролетта до есента 1944 г., но бил објавен во јуни 1945 г. и, според тоа, може да се смета за првиот роман за движењето на отпорот во Италија. Тоа е роман што својата инспирација ја црпи од личното искуство на авторот во времето на движењето на отпорот во градот Милано.

Главниот јунак, со прекар Ене 2, ѝ припаѓа на една од вооружените групи наречени ГАП, кои дејствувале во окупираните градови и вршеле атентати, акции на саботажа на стратегиски и воени цели, и герилски акции против нацистите и фашистите.

Насловот на делото често бил погрешно толкуван, во смисла дека се прави разлика меѓу луѓето, од една, и нелуѓето, од друга страна, што е погрешно толкување не само на насловот туку и на некои важни делови и на смислата на самиот роман.

И покрај тоа што по ова прашање Виторини секогаш бил сосема јасен, ${ }^{2}$ многу често романот се чита како јасна поделба на луѓе и нелуѓе. На пример, Де Никола забележува дека во Луг̇e и нелуѓе сите ликови на партизани се позитивни, додека фашистите се сите негативни и се „најапсолутното претставување на злото“, и дека целата нарација е базирана врз „неспорниот контраст меѓу двете групации“ (De Nicola 2014: 53).

\footnotetext{
1 „Движењето на отпорот во италијанскиот и во македонскиот роман: низ делата на Фенољо, Калвино, Виторини, Јаневски, Малески и Солев“, одбранета на Филолошкот факултет „Блаже Конески“ во Скопје во 2018 година. Во текстот има податоци и цитати што се дел од дисертацијата, иако таму не била направена споредба меѓу романите во ваква форма. Во текстовите и материјалите што ги проучувавме немаме сретнато споредба што е тема на овој текст.

${ }^{2}$ Виторини му пишува на Мишел Арно, преведувачот на неговиот роман на француски јазик: „Италијанскиот наслов на овој роман, Uomini e по, значи токму дека ние, луѓето, можеме исто така да бидеме 'нелуѓе'. Со други зборови, неговата цел е да потсети дека во човекот постојат многу нечовечки можности. Но, тој не го дели човештвото на два дела, едниот целосно човечен, другиот сосема нечовечен“" (Vittorini 2008: 338).
} 
Мислиме дека истата поделба што ја критикува Виторини е имплицитна и во насловот на преводот Луг̇e и нелуг̇e на македонски јазик. ${ }^{3}$ Постои објективен проблем да се преведе насловот, бидејќи и на италијански јазик ја содржи поделбата што е предмет на критиката на Виторини.

Хронотопот е точно определен веќе во првата реченица на романот: „Зимата во 1944 година во Милано беше најблагата што ја имавме од пред четврт век“ (Vittorini 2010: 3). Ене 2 е псевдоним на главниот лик, скратено од Навиљо (N2), што е името на квартот каде што живее и на групата чиј водач е. Тој е интелектуалец, што е редок случај за борците, дури и во градот. Сепак, не знаеме точно која му е професијата на Ене 2. Малку знаеме и за неговата идеологијата, а уште помалку за неговото минато: знаеме само дека бил во затвор од политички причини од мај до август 1943 г., а знаеме и дека со ликот со прекар Грах се познава уште од времето кога бил осуден на прогонство, што значи дека бил противник на фашизмот уште пред војната.

Другите ликови исто така се дадени со псевдоними. Вистински имиња имаат само женските ликови: Берта, Лорена и Санта. Можеби Берта, жената во која е вљубен Ене 2, и не е лик, туку е еден од најапстрактните симболи во делото, како што тврди Новента. Берта се појавува двапати, и двапати меѓу нив се повторува истата сцена. Таа му вели да ја води „некаде“, бидејќи е негова, тој ја води, и кога треба да стане „негова“ и физички, таа го менува мислењето и го одложува нивното „спојување“, бидејќи не разговарала со својот маж (за да го прекине бракот). Берта е, сепак, присутна на многу страници од книгата, но како опсесија, како сон, како копнеж, понекогаш и како сеќавање. Според оваа карактеристика, постои сличност меѓу ликот на Берта и ликот на Фулвија од Привайнойо йрамање на Фенољо. И Фулвија е многу важен елемент во делото, љубовта кон неа, впрочем, е основната сила што го движи протагонистот, но таа се појавува само посредно, во флешбековите од минатото, во мислите.

Како лик, Берта се појавува на неколку страници, но не во истите сцени co Ене 2, во едната сцена го гледа масакрот на плоштадот Августо, па оди кај Селва и разговара со неа. Во вториот дел од романот таа едноставно исчезнува, тој ја чека, присутна е како некој што го чекаат. Слично на симболичните ликови во романот Разг̄овор на Сицилија, ${ }^{4}$ Берта е симбол на недостижната среќа и љубов и потрагата по неа или, подобро кажано, на нејзиното очекување. На онаа среќа за која опсесивно зборува Селва.

Селва е, исто така, лик симбол, таа е медијатор меѓу статичката состојба на непродуктивност во која се наоѓa протагонистот и активната состојба на ерос и иднина. Таа се појавува двапати, секогаш со истата приказна за тоа дека човек мора да има жена и дека е тоа начин да биде среќен, а ако човекот не е среќен, тогаш ни нивната борба ништо не вреди. Берта веќе нема да се појави

\footnotetext{
3 Луѓ и нелуѓe, Кочо Рацин, 1956, превод и поговор Владо Малески. Малески е сосема свесен за оваа поделба и на крајот од својот поговор вели: „Она што останува трајно во човека, она што го понесува - тоа е поезијата што звучи со силата на музиката, тоа е сознанието на праведноста на судирот: луѓе против нелуѓе. Луѓе, а не човек“ (Виторини 1956: 301).

${ }^{4}$ Conversazione in Sicilia е најпознатиот роман на Виторини, објавен во 1941 година, прво кај издавачот Паренти од Фиренца (со насловот сменет во Nome e lagrime - Име и солзи), а потоа истата година во второ издание кај Бомпјани од Рим со оригиналниот наслов.
} 
„лично“ во вториот дел од романот. Малку порано, во една сцена, и таа самата се срами од својот малограѓански морал пред мртвите што ги гледа.

Основната поделба во романот е на приватен и на јавен план. Како и во

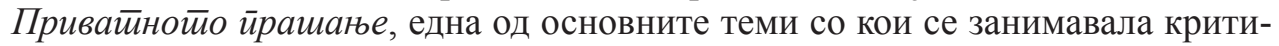
ката бил токму односот меѓу приватното (во случај на Привайнойо йрашағье љубовната врска на протагонистот, во Луѓе и нелуѓе исто, само со уште некои приватни прашања), наспроти јавното прашање, односно активноста на протагонистот како учесник во партизанската војна.

\section{1 Љубовната приказна во романот Луѓe и нелуѓe}

Со оглед на годината на објавувањето и фактот што романот на Виторини бил перципиран како книга за движењето на отпорот, ова е недоволно истражен аспект, загатнат дури во поновата критика (кај Гвидо Бонсавер, на пример), и се однесува на проекцијата на сентименталната приказна на самиот Виторини во овој роман. Се разбира, не станува збор за некакво буквално прикажување на приказната на Виторини во романот, туку за извесна паралела што може да се повлече меѓу неговиот приватен љубовен живот и животот на протагонистот на Луг̌́ и нелуѓe Ене 2. За време на последната година од војната, врската меѓу Виторини и Џинета Вариско беше факт што постоеше веќе десетина години, иако ниеден од нив не беше формално разведен. Во Луѓe u нелуѓe Ене 2 и Берта се запознале десет години пред тоа и таа тогаш била штотуку мажена. Во тој период, како и Ене 2, и Виторини е во илегала и е во врска со мажена жена што не е член на движењето на отпорот. „Грижите и стравовите на ваквата положба го сочинуваат суштинскиот дел на Луѓe и нелуѓe и, всушност, автобиографските повикувања се појавуваат јасно на површината на раскажувањето“ (Bonsaver 2008: 147). На пример, описот на детството на двајцата љубовници - тој е од Сицилија, таа од Ломбардија - како и споменување на нејзиниот стан во Милано, кој бил уништен во бомбардирање, па таа била принудена да се пресели со свекорот и свекрвата надвор од градот, токму во Варезе, каде што живеела Џинета Вариско. Оттаму Бонсавер ќе зборува за „двојната природа на романот, поделен меѓу интимистичката нарација и опис на партизанската борба“" (ibid., 147).

Тезата на Џакомо Новента е дека ова не е само роман со политичка заднина за движењето на отпорот во Милано - ова е љубовна приказна. Односно, ова е првенствено љубовна приказна.

\section{2 Тезата за „големата љубов“ како централен мотив во романот}

Според Новента, ова е ,љубовен роман“, кој својата вредност, дури и политичката, ја црпи од сентименталниот мотив, а не „од механичките и апстрактни сцени на движењето на отпорот, бидејќи во него се отсликува трагедијата на нашата младина и на нашата култура“" (Noventa 1960: 59).

Ликот на Берта, главно обвинувана дека е буржоаска малограѓанка, се однесува така како што се однесува, бидејќи таа „сака да биде третирана како суштество, а не како симбол“ (ibid., 42). Ова е целосно спротивна идеја за 
ликот на Берта во однос на најголемиот дел од критиката што дотогаш се занимавала со овој роман. Поетот Новента на сосема нов и оригинален начин го третира овој лик, но ништо во текстот на Виторини не ги демантира неговите тези.

„Таа тајна, сепак, сите ја знаеме: не е доволна волјата на жената што велиме дека ја сакаме за да ја изгасне големата љубов: ние не можеме да се откажеме од реториката без да се откажеме од нашето човечко достоинство“ (ibid., 42-43). Во разликата меѓу љубовта и „пустината“ на љубовта, Виторини укажува на разликата меѓу љубовта и сексот. Тоа е како да си гладен и да јадеш земја место леб, вели Виторини, како да пиеш, а стануваш уште пожеден, односно само си ја извалкал својата жед. Зашто, таа жед е по една жена и само со неа може да се изгаси. ,Човекот е победен не во љубовта, туку во нејзината пустина“", вели Виторини (Vittorini 2010: 38).

Берта е навистина малку развиен лик и покрај влијанието што Виторини ѝ го припишува. Сметаме дека нејзината нерешителност да се одлучи меѓу Ене 2 и својот маж не се должи на нејзиниот „малограѓански морал“, туку на фактот што не го гледа своето место во животот на Ене 2.

„Таа не ја сака судбината на изговор. Не сака да биде сѐ. Кога нешто такво се бара од една жена, тоа не е речиси никогаш поради домот и почовечкиот живот, туку поради реториката на тие нешта“" (Noventa 1960: 51). На пример, кога тој ќе ѝ рече: „Ти си сѐ. Си била и си сѐ што имам“ (Vittorini 2010: 132). Со помош на својот веќе испробан лирско-алузивен стил, ${ }^{5}$ тој ѝ припишува чудесни моќи и таа лека-полека станува единствената причина на неговата егзистенција. Таа била и детство, и сопруга, и планини. Тоа е огромна одговорност и не е чудо што таа му бега: ѝ дава преголем товар. Но, како што кажа Новента, тоа е реторика, односно зборови што „убаво звучат“, но се без суштина.

Што велат „фактите“ од романот? Ене 2 бил уапсен во мај и бил во затвор до средината на август. И, Берта секој ден, вели таа, го чекала пред вратата од затворот. А, тој откога излегол, не ѝ се јавил. Сега е јануари. Факт е, исто така, дека се преселила, ама не ја нашол, зашто не ја барал. Но, тој вели дека ѝ го пишувал името на зидот од ќелијата. „Те барав без да те барам - рече Ене 2. Не правев ништо друго. Не ни работев“" (Vittorini 2010: 17). Гледаме дека не ја барал поради чувството на статичност, пасивност во кое западнал. Очигледна е кризата на протагонистот, која всушност, ќе биде вистинската причина за неговиот пораз, а не ваквата апстрактна љубов кон Берта.

Кај самиот Виторини, како и кај неговиот јунак Ене 2, постојат низа контрадикции што не се разрешени, а кои се теми во романот: контрастот меѓу насилството и ненасилството, меѓу нехуманоста и хуманоста, меѓу интелектуалецот и човекот од акција, меѓу писателот и комунистот. Митот за големата љубов би требало да разреши сѐ, да одговори на најважните дилеми, но не може да го стори тоа, зашто е лажна слика на добрината, на домот, на семејството. Што ќе направи Ене 2? Ке се откаже ли од поезијата или, пак, ќе се откаже од големата љубов? Ке одбере да се откаже од Берта, иако тоа никогаш експлицитно не го кажува. Таа, рековме, во вториот дел од романот исчезнува.

\footnotetext{
${ }_{5}^{5}$ Во романот Разговор на Сицилија (1941).
} 
Тој ја чека, но не ја бара. На крајот од романот, иако знае дека непријателите доаѓаат, тој не бега, бидејќи ,jа чека Берта“. Таа е изговор за неговата пасивност во решавачките моменти што ќе доведат до неговата смрт, односно до неговото „самоубиство со помош на непријателот“.

Како што веќе рековме, за Новента Берта е навистина централен и единствениот автентичен лик во книгата, и не сака да биде третирана како симбол. Берта знае дека сериозноста на животот не ѝ дозволува да биде жена на двајца мажи. Со ваквото видување на оваа љубовна врска Новента ,jа рехабилитира“ Берта од обвинувањата дека е малограѓанка што води сметка за сексуален морал додека светот пропаѓа и ѝ дава дигнитет на жена што не сака да биде апстракција. Не ја споделуваме оваа теза докрај. Мислиме дека машкиот протагонист ја води играта, не таа. Од тоа што го читаме во романот, не успеваме да дознаеме што сака или не сака Берта. Излегува дека и Ене 2, како и Милтон

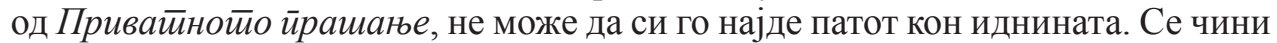
дека Ене 2 ја одбира доброволната смрт, зашто не може да ја освои Берта. Но, можеби е поточно да се рече дека тој не може да биде со Берта токму зашто не знае како да живее, не знае да ги разреши насобраните контрадикции во својот живот. Фактот што не знае или не може да живее доведува до неговата смрт. Берта е само изговор.

\section{3 Објавената верзија на романот Приватното прашање}

Романот првпат е објавен од Гарsанти во 1963 (под наслов Ден на ог̈ной), заедно со неколку раскази, и има 13 поглавја. Во планот на Фенољо за објавување се појавуваат само расказите, не и романот, кој ќе биде објавен два месеца по смртта на авторот.

Што се однесува до хронотопот, станува збор за врнежливиот ноември 1944 г., за време на акцијата за чистење на теренот на фашистите во градот Алба и во нејзината околина. Una questione privata (Привайно йрамање) е насловот што Фенољо го употребувал зборувајќи со својата жена за приказната на Милтон, иако лајтмотивот и можниот наслов на делото била песната Далеку зая облаиите (Over the Rainbow $\left.{ }^{6}\right)$.

Во средиштето на делото е ликот на партизан со англиско книжевно име Милтон. Романот започнува со него, како ја гледа куќата на Фулвија, девојката од Торино што ја запознал пред војната. Поттикнат од носталгијата, иако знае дека Фулвија не е таму веќе една година, оди во вилата и сака да ја види чуварката и да разговара со неа. Дијалогот со таа жена е од централна важност за текот на настаните во романот. Од неа дознава дека, кога доагал неговиот пријател Џорџо да ја посети Фулвија, тие сакале да се осамуваат. Жената алудира на тоа дека меѓу нив двајца имало поинаков однос одошто меѓу него и Фулвија. Тоа се однесувало особено на периодот од летото 1943 г., па сѐ до септември, до нејзиното заминување. Од тој момент го обзема апсурдната желба да дознае дали имало нешто меѓу девојката во која бил вљубен и убавиот и богат Џорџо. Тргнува да го бара во неговата бригада за да го праша за природата на нивниот однос. Но, дознава дека го заробиле фашистите. Се

\footnotetext{
${ }^{6}$ Песната што ја пееше Џуди Гарланд во филмот Волиебникот од Оз (1939).
} 
обидува да го ослободи со размена со фашист. Сепак, принуден е да го убие фашистот што го заробил, затоа што тој во паника почнува да бега. Додека се обидува повторно да се пробие до вилата, овој пат за пак да ја препраша чуварката, да провери да не разбрал погрешно, налетува на група од 50 фашисти. Бега, но дали ќе им избега? Пред една шума ќе се струполи. Така завршува романот.

\section{1 Автобиографските елементи и љубовниот триаголник}

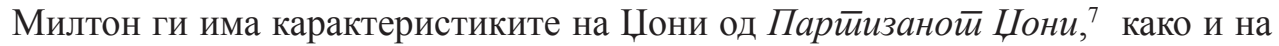
самиот автор, Фенољо. И тој е грд и вљубен во англиската книжевност. Во романот има многу интертекстуални упатувања. Би можело да се рече дека и „врската“" меѓу Милтон и Фулвија е чисто „книжевна“, бидејќи се одвива низ книжевноста, низ разговорите за литературата што ги водат, низ книгите што тој ѝ ги подарува, како на пример Теса оg Убервилови. Й подарил и плоча што станала музичка подлога на романот, песната Over the Rainbow. Тој поради неа почнува да преведува од англиски, поради неа и пишува, таа му наредува да ѝ пишува писма. Кога била објавена книгата, сите што го познавале Фенољо во ликот на Фулвија ја препознале Бенедета Фереро, поточно Мима, како што сите ја викале. И таа подоцна им се приклучила на партизаните, во Косано, а по војната се омажила и отишла да живее во Рим. По војната останала пријателка со Бепе.

Освен Милтон, како што видовме, главни ликови се и Фулвија и Џорџо Клеричи. Најинтересната карактеристика на овие ликови, кои ги мотивираат сите движења на протагонистот, е дека тие ниеднаш не се појавуваат „во живо“, туку само во многубројните флешбекови на Милтон од времето на нивното дружење.

Фулвија е убава, богата и каприциозна. Кога се запознаваат, преку Џорџо Клеричи, Фулвија има 16 години и е избегана од Торино поради стравот од бомбардирањата. Има многу плочи и сака да чита. Низ флешбековите на Милтон, во детали се гледа различниот однос на Фулвија со Џорџо Клеричи: Милтон не танцува, па обично таа танцува со Џорџо, додека тој ги менува плочите. Во друг флешбек, особено суров, Фулвија игра тенис со Џорџо додека тој ги гледа, без пари да си купи пијачка, со цигара што ќе ја пуши цел ден и песна на Јејтс во џебот. Фулвија е константна фигура и во сите претходни редакции на романот, и го претставува неостварувањето на љубовните чувства на главниот лик, без притоа присуството на ривалот да има решителна улога во тоа (во Привайнойо йрашање видовме дека е тоа Џорџо), зашто девојката го одбива протагонистот и во претходните редакции, пред воопшто да се појави ликот на ривалот.

Темата на љубовниот триаголник е маргинална, смета Де Никола (De Nicola 1989: 160), и како да ѝ е подредена на мачната егзистенцијална ситуација на Милтон, кого Фулвија го прифаќа поради неговата интелектуална

\footnotetext{
${ }^{7}$ Beppe Fenoglio. 1992. Il partigiano Johnny in Romanzi e racconti. Edizione completa a cura di Dante Isella, Biblioteca della Pléiade, Paris: Einaudi-Gallimard: 430-863. Партизанот Џони е најпознатиот роман на Фенољо, првпат објавен постхумно во 1968 г. кај издавачот Еинауди од Торино.
} 
дарба, но го одбива поради неговата надворешност, непривлечниот физички изглед и поради скромното социјално потекло.

Романот е речиси целиот базиран врз гледната точка на Милтон:

Сеќавањата на Милтон се уште од почетокот суштината на ликот и ја скицираат неговата „книжевна љубов“. Шемата произлегува од настаните и од културата на самиот Фенољо: еден „триаголник“, повеќе романтичен отколку буржоаски (...) што личи на Орканскитее височини. (Bigazzi 1983: 77)

Бигаци ќе направи анализа и споредба меѓу двата романа и ликовите на Хитклиф, Катерина и Џорџо Клеричи. Често ја нагласува неспособноста на ликот на Милтон да ја види реалноста, па понекогаш контрастот меѓу илузијата и реалноста станува дури ироничен: додека е во потрага по тоа „далеку“, не гледа што му се случува пред носот.

Каков е ривалот? Џорџо Клеричи е „убав“, „татин син“, не го сакаат во бригадата и го викаат „Свилени Пижами“ и Мате, но сепак, го сметаат за храбар партизан. По заробувањето, на Џорџо црно му се пишува, бидејќи, иако е од „бадолјанците“ (значи, од „сините“ партизани, не од „црвените“, и затоа има помалку шанси да го стрелаат), бил фатен со униформа и со оружје, за што следува смртна казна. Тоа ја прави уште потрескавична потрагата на Милтон по начин да го спаси, затоа што тој е единствениот што ,знае“ и многу брзо би можел да биде стрелан.

Фенољо тука се опишува себеси од физичка гледна точка, но сето тоа не е доволно да го сметаме Милтон за двојник на писателот. Во однос на овој роман најмалку се поставувало прашањето на автобиографизмот на Фенољо, иако опишаните настани имаат врска со животот на авторот. Мислиме дека токму во овој роман Фенољо мајсторски успева да ја води „играта на огледалата“" меѓу протагонистот (кој веќе е лик што настанал од удвојувањето на еден лик, Џорџо, од претходните редакции на делото, во соперниците Џорџо и Милтон), раскажувачот, кој ни ги дава информациите што протагонистот не ги знае, или не сака да ги знае, или е во потрага по нив, и авторот што му дал на Милтон некои од сопствените карактеристики, но потоа го оставил на својата судбина.

\section{2 Потрага по вистината како клучен дел од „приватното прашање“}

Но утре ќе дознае. Не можеше веќе да живее без да знае, а особено не можеше да умре без да знае, во една епоха во која момчињата како него беа поблиску до смртта отколку до животот. Ке се откаже од сѐ, само да дојде до вистината... Денес одеднаш стана неупотреблив, половина ден или недела, или месец, сѐ додека не дознае. Потоа можеби одново ќе биде способен да направи нешто за своите соборци, против фашистите, за слободата. (Fenoglio 1992: 1032) )

Во овие цитати јасно се гледа дека потрагата по вистината, односно „приватното прашање“, за Милтон станало поважно од ,јавното прашање“, од самата борба за слобода. Таа останува неговата основна задача, но прво мора 
да го најде Џорџо, мора да ја дознае вистината за неговиот однос со Фулвија: „Вистината. Партија вистина меѓу мене и него. Ќе мора да ми каже, како еден осуденик на смрт на друг“ (ibid., 1033).

Се гледа дека сите потези на овој лик се насочени кон тоа да ја „дознае“ вистината, да копа по минатото. Неговата потрага е очајничка по нешто што веќе се случило, а претставува пропаст на неговата љубов и на единствената сила што го држи во животот низ хаосот и насилството на војната. Во таа сѐ поопсесивна и поочајничка потрага се губат сите други цели на неговата борба. Постојаното присуство на смртта е многу важен фактор на неговата опсесија по вистината. Бидејќи, како што не може да живее без вистината, не може да умре без неа, во епохата во која е многу полесно да се умре одошто да се живее. Затоа,

неговата опсесија е како безумна пружина што го тера да се движи во целосната осаменост низ еден свет веќе сам по себе лишен од смисла. Неговите движења, во еден пејзаж нурнат во магла и мраз, имаат во себе нешто слепо, небаре се водени од некоја невидлива и непријателска сила; соборците, местата што ги допира, настаните во кои учествува, остануваат туѓ за него; важна е само непоколебливата упорност на неговата потрага, желбата да дознае нешто што ќе мора да го повреди и да го фрли во очај, но што тој нема да стигне да го дознае. (Lagorio 1970: 110)

Привайнойо йрашање, според многумина, претставува најзначајно дело инспирирано од темите на движењето на отпорот и на ослободувањето.

Во писмата на режисерот Квести и на издавачот Гарsанти, ${ }^{8}$ Фенољо јасно ги изложува своите намери во врска со целта и структурата на овој роман. Накусо, тој сака во една единствена епизода да се обиде да ги внесе сите елементи и аспекти од граѓанската војна. Од неколкуте редакции на романот можеме да заклучиме дека Фенољо многу се премислувал во својата елаборација. Зошто авторот толку пати чувствува потреба сѐ да смени? Кога конечно со сигурност го определил приватното прашање/потрагата како централен мотив на делото,

проблемот ќе биде првенствено во тоа да стигне до ригорозна тематска концентрација преку елиминација на сето она (документаризам, на пример, и премногу раширените флешбекови) што може на некој начин да ја забави драматичната тензија на потрагата (quête). (Saccone 1988: 138)

Саконе зборуваше за quête, а Калвино 9 веќе потсети на витешките романи,

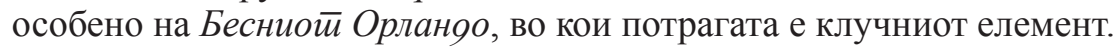

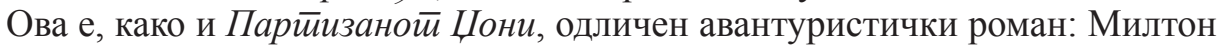
е во потрага по нешто (по вистината), но за да дојде до неа е во потрага по некој (прво по Џорџо Клеричи, а потоа и по некој фашист што ќе го замени за

\footnotetext{
${ }^{8}$ Писмата ги собрал и ги објавил Лука Буфано: Fenoglio. В. 2002. Lettere 1940-1962. Alba: Fondazione Ferrero.

${ }^{9}$ Калвино ова го напишал во прочуениот предговор на својот роман Патека кон пајаковите гнезда во изданието од 1964 година кај издавачот Еинауди од Торино. Првото издание на овој роман, кај истиот издавач, е од 1947 година.
} 
него), и сето тоа се одвива во Алба, додека непријателот го чисти теренот од партизаните, значи и гонителот е гонет.

Ова е роман и за крајот на една илузија, која сите знаеме дека била илузија „исфрлување од замислениот рај, или поточно, од неговите врати“ (ibid., 142). Тоа што го придвижува не е љубомората, туку суштината е во таа илузија, единствената што го држи во животот,

потрага што всушност има функција да го одложи, низ трескавична активност, неизбежното препознавање, (...) откритие пред кое е смртно опасно да се отворат очите: Медузата пред чијшто неиздржлив поглед се претпочита секакво бегство. (ibid., 142)

Значи, потрагата на Милтон по вистината би можела да се толкува како бегство од неа.

На крајот од романот се случува бегството на Милтон од фашистите и тоа претставува една од најубавите сцени што ги напишал Фенољо. На последната страница, додека бега од фашистите, ѝ вели на Фулвија во мислите: „Фулвија, само што не ме уби!“ (Fenoglio 1992: 1127) Интересно е, но не и невообичаено, тоа што Фулвија се појавува токму кога размислува за смртта. И фашистите и Фулвија можат да го убијат, но за него претставуваат и причина, можеби единствената, за живот.

Милтон веќе знае дека Фулвија не го сака. Од флешбековите од минатото, од описите на ситуациите, раскажувачот ни дава ситуација во која на сите сѐ им е јасно, освен на протагонистот. Така се чини. Смртта го надвиснува целото ова дело без надеж, како облаците што без прекин го покриваат небото. Веќе рековме, според Саконе, потрагата по вистината е само одложување на соочувањето со вистината. Како што се доближува моментот на смртта, така ликот веќе не може да живее без конечната пресметка со илузиите. Затоа не е

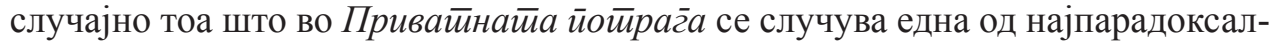
ните можни ситуации - на потрага што не сака да го најде она што го бара. „Неслучајно романот почнува со откритие на нешто што овој лик отсекогаш (...) го знаел: дека Фулвија не го сака. Оттука доаѓа лажната потрага - како онаа на Сизиф - без надеж“ (Saccone 1988: XII).

\section{3 Војната како изговор}

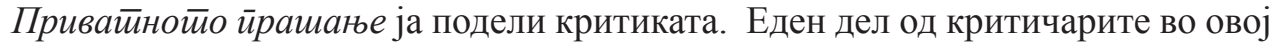
роман гледаат класик, други сметаат дека со ова дело Фенољо, во основа, ја сквернави својата вокација на писател на војната. Едно од основните прашања околу кое се кршат копјата е дали во Привайнойо йрашање има неурамнотеженост меѓу двете теми што се преплетуваат во авантурата на Милтон и дали оригиналноста на ова дело треба да се бара во дијалектичката и, истовремено, хармонична врска меѓу сентименталните и воените причини.

Во односот меѓу овие два мотива, сентиментално-љубовниот се чини дека превладува и тоа им пречи на идеолошки настроените критичари. Тие сметаат дека со тоа другиот мотив, оној на движењето на отпорот, се сведува на изговор, на потпора. Лајоло не се согласува со констатацијата дека партизанската 
војна во ова дело е само изговор. „Без тој изговор романот не постои. Тензијата на потрагата по вистина за Фулвија е сета поврзана со таа атмосфера. (...) Милтон е љубоморен на знаењето, не на Клеричи““ (Lajolo 1970: 109).

И ова е првиот роман во кој Фенољо ја наоѓа жената, не сексот. Жена што никогаш не се допира, што постои само во сеќавањата, како меморија, како несигурност. Па, сепак, оваа слика ја проникнува секоја страница на оваа книга. (ibid., 110)

Благодарение на ова преплетување на мотивите, Валтер Мауро го споредува романот со Послеянийе йисма на Јакойо Орйис од Уго Фосколо. Но, според него, наспроти она што се случува во Орйuc, кај Фенољо приватното прашање ќе го надвладее јавното, односно војната. И ние се согласуваме со тезата, како што, впрочем, вели и самиот наслов на делото, дека „приватното прашање“, односно вљубеноста на главниот лик во овој роман, превладува над прашањата поврзани со војната. Мауро ја нарекува Милтоновата потрага „нервозна и халуцинантна“ (Mauro 1972: 95), која го доведува до смрт. Ние не сме сигурни дека тој умира, туку сметаме дека Фенољо намерно остава крај што може да се толкува на повеќе начини, како што, всушност, прави и во

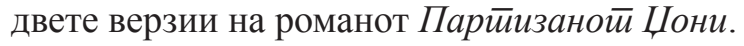

Приватната приказна на протагонистот се преплетува на начин што не е механички со претставувањето на околината, на животот, на обичаите, на партизанските битки. Не би можело да се рече дека тој дел од партизанскиот живот е само изговор за да ја прикаже љубовната случка. Реалноста е дека двата мотиви - љубовниот и мотивот на движењето на отпорот, имаат потреба еден од друг, заемно се осветлуваат, во едно навистина успешно спојување, ретко во расказите од овој вид.

\section{4 Улогата на љубовниот мотив во крајот на романот}

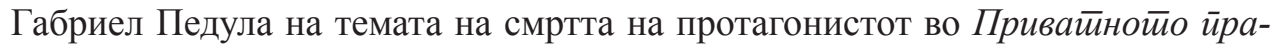
шање, а и воопшто во делата на Фенољо, й посветил цело поглавје во својата книга за Фенољо, Пояолг̄uот̄ $\bar{u} а \bar{u}$. Тој вели дека секојпат кога Фенољо не знае како да ја заврши книгата, на крајот го избира најрадикалниот и најнасилен пат, односно го убива протагонистот (Pedullà 2001: 120). Во критиката по ова прашање постојат две ,школи“: оние што мислат дека Привайнойо йрашање не е завршена книга (Џорџо Барбери Сквароти, Марија Корти, Давиде Лајоло, Џина Лагорио), па следствено на тоа - Милтон не е мртов, и оние, како Педула, што мислат дека смртта на Милтон е единствениот логичен исход од лудата трка на крајот од книгата, на лудата трка од моментот кога дознава за Фулвија (ibid., 125). Значи, и крајот, односно смртта на протагонистот, е поврзан со љубовното прашање.

Судбината се остварува. Уште од почетокот, уште од моментот кога ќе ја открие врската на Фулвија со Џорџо, Милтон само ќе се врти во празно во потрага по куршумот што ќе го потврди она што веќе им е јасно на сите читатели. Единаесет поглавја Смртта му остава време да стане свесен за сопствениот 
пораз и за рушењето на сите илузии, и сега дури би можело да се рече дека не го убиле куршумите, туку празнината и очајот на животот без Фулвија. Во меѓувреме: пауза, одложување, кошмар што ја придружуваат последната агонија на осудениот. (ibid., 129)

Во однос на прашањето колкава „тежина“ во романот има љубовниот мотив за романот, па и за смртта на протагонистот, би рекле дека овој роман претставува пресврт во пишувањето на Фенољо. Тој и понатаму ѝ останува верен на партизанската тематика, но во неа вметнува љубовен мотив, кој станува централен за целиот роман: тој го придвижува протагонистот, тој е причина за неговата смрт. Низ долгата обработка на темите, на мотивите, низ усовршувањето на стилот, Фенољо сфатил дека за војната може да зборува не

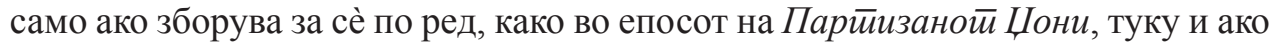
тоа „сѐ““ го стави во четири дена на војната, во кои, патем, ликот ќе мисли на нешто друго.

\section{4 Хемингвеј - модел за двајцата писатели}

Познато е дека во италијанска книжевност немало модел за приказна со граѓанската војна во заднина. Виторини го имаше тој модел во еден од „своите“" американски автори: романот на Хемингвеј објавен во Њујорк во 1940 година, кој Виторини веќе во 1942 г. го прочитал и почнал да го преведува, како што ќе открие на 29 септември 1945 г. во првиот број на „Политекнико“ ${ }^{10}$ каде што на третата страница, пред првото продолжение на романот $3 a$

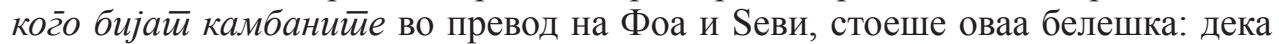
во 1942 успеал да добие од Швајцарија примерок од For whous the bells tolls (sic), почнал да го преведува, но кога бил уапсен го загубил и не можел потоа да му се посвети поради илегалната борба. Овој роман е модел и за Фенољо, ${ }^{11}$ особено во формата на кратките дијалози.

Постојат тематски сличности меѓу романот на Хемингвеј и Луг̌́ и нелуѓe. „Како што веќе укажа на времето Марио Прац, и подоцна Доналд Хејни, заплетот во двата романи е структуриран околу епизодата на крајната жртва на протагонистот“ (Bonsaver 2008: 151-2). Сепак, според нас, има една голема разлика што ги одвојува романите на Хемингвеј и на Виторини: смртта на Роберт Џордан е херојска, ама и логична и неминовна според ситуацијата во која се нашла групата, додека Ене 2 сам ја создава безизлезната ситуација во која ќе загине. Хемингвеј често се споменува како модел и за пишувањето на Фенољо, за неговата техника на раскажување „низ приказни“, како што прави

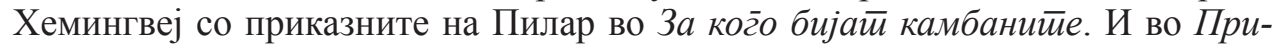

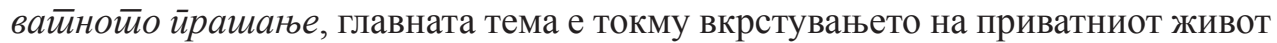
и на вооружената борба, и ова е сигурно роман за жртвувањето на главниот лик, но не во таква благородна смисла како што е романтичниот херојски гест

10 "Il Politecnico" (1945-1947) - списание за политика и култура основано од Виторини.

${ }^{11}$ И во романите на Виторини и Фенољо, слично на ликот на Роберт Џордан, протагонистот е интелектуалец, алтер его на авторот, и се бори во граѓанска војна против фашистите. 
на Роберт Џордан. Сепак, треба да се напомене дека и Роберт Џордан, како и Ене 2 и Милтон, со своите постапки извршуваат некој вид самоубиство со помош на непријателот. Точно е дека Милтон бега од фашистите, но исто така, точно е и дека тој веќе нема никаква работа во куќата на Фулвија, каде што ќе ги сретне (случајно?) фашистите. Ене 2 знае дека се доведува во смртна опасност ако чека, но чека зашто „можеби ќе дојде Берта“, иако нема никакви индиции ниту најава дека тоа ќе се случи. Неговиот гест е гест на нихилистичко отфрлување на животот од приватни причини и нема никаква врска со херојството.

\section{5. Заклучок}

Во споредбата меѓу романите забележливи се неколку елементи што ги спојуваат. Станува збор за дела чија централна тема би требало да биде Втората светска војна, а во кои е присутен - и во помала или во поголема мера пресуден - љубовниот мотив.

Во двата романа има автобиографски елементи: кај Виторини тие елементи произлегуваат од истата ситуација во која се наоѓаат во текот на војната тој и неговиот протагонист - како илегалци во окупираниот Милано, веќе десет години во врска со мажена жена, која нема врска со движењето на отпорот. За среќа, за разлика од романот, љубовната приказна на Виторини со Џована Вариско ќе има среќен крај. Кај Фенољо протагонистот Милтон (како и во сите негови други романи) ги носи карактеристиките на самиот автор, како во физичкиот изглед (грдо лице, висок, со долги нозе), така и во другите карактеристики: вљубен во англискиот јазик и книжевност, со скромно потекло, срамежлив итн. И ликот на Фулвија е препознатлив во неговиот живот, но не знаеме дали навистина постоела љубовна приказна меѓу него и Мима.

И двата романа имаат еден заеднички модел, романот на Хемингвеј За ког̄o

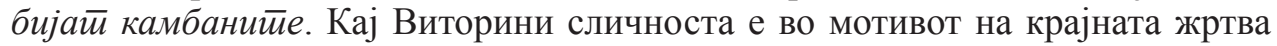
на протагонистот, на херојската смрт. Тоа е модел за Фенољо за раскажување „низ приказни“ и за кратките и природни дијалози.

Во однос на еротските елементи и сексот, тој кај Виторини се споредува со пустина, кога е само физички однос и кога не е поврзан со саканата жена, а се однесува и на самиот живот: и животот е пустина без љубената жена. Кај Фенољо воопшто не постојат такви елементи (барем не меѓу протагонистот и неговата сакана), односно љубовниот однос е платонски и чисто „книжевен“: се сведува на разговори за литературата, на слушање музика итн.

Кај двајцата писатели протагонистките, и покрај огромното влијание што го имаат, не се појавуваат „лично“. Кај Фенољо Фулвија се појавува во „флешбековите“ од времето на нивната дружба, а кај Виторини Берта е лик што тој го чека. Таа е симбол на надеж, на иднина, и кога таа во вториот дел од романот престанува да се појавува, ја нема ни надежта ни иднината.

Кај Фенољо таа „надеж“ е поврзана со една илузија. Целиот роман претставува луда трка во „потрага по вистината“" која протагонистот, всушност, не сака да ја најде, бидејќи би ја разбила неговата илузија, единственото нешто што го одржува во животот. Така, тој со „потрагата“ го одложува соочувањето 
со вистината. Таква потрага во романот на Виторини не постои, но постои уште еден елемент што ги доближува двете дела: и двајцата протагонисти не можат да си го најдат патот кон иднината и во тоа се состои нивниот пораз. Следствено на тоа, и нивната смрт е логична последица на тој пораз, и двајца стануваат самоубијци „со помош на непријателот“. Значи, војната е изговор за смртта на главните јунаци, чија вистинска причина е љубовниот пораз и неразрешените внатрешни конфликти (кај јунакот на Виторини).

\section{Библиографија}

Bigazzi, R. (1983). Fenoglio: Personaggi e narratori. Roma: Salerno editrice.

Bonsaver, G. (2008). Elio Vittorini, letteratura in tensione. Firenze: Franco Cesati editore.

Calvino, I. (1991). Prefazione 1964 al Sentiero dei nidi di ragno, in Romanzi e racconti, Milano: Mondadori: 1185-1204.

De Nicola, F. (1976). Fenoglio Partigiano e Scrittore. Roma: Argileto editori.

De Nicola, F. (1989). Introduzione a Fenoglio. Roma-Bari: Laterza.

De Nicola, F. (2014). Uomini e no: modello (mancato?) di romanzo resistenziale. Studi goriziani, Vol 107: 50-59.

Fenoglio, B. (1992). Una questione privata in Romanzi e racconti. Paris: Einaudi-Gallimard: 1009-1127.

Lajolo, D. (1970). Pavese e Fenoglio. Firenze: Vallecchi.

Mauro, W. (1972). Invito alla lettura di Beppe Fenoglio. Milano: Mursia.

Noventa, G. (1960). Il grande amore in 'Uomini e no' di Elio Vittorini e in altri uomini e libri. Milano: All'insegna del pesce d'oro.

Pedullà, G. (2001). La strada più lunga. Sulle tracce di Beppe Fenoglio. Roma: Donzelli editore.

Saccone, E. (1988). Fenoglio. I testi, l'opera. Milano: Einaudi.

Vittorini, E. (2010). Uomini e no. Milano: Oscar Mondadori.

Vittorini, E. (2008). Letteratura arte società. Articoli e interventi 1938-1965. Torino: Einaudi.

Виторини, Е. (1956). Луѓe и нелуг̇e. Скопје: Кочо Рацин. [Vitorini, Е. (1956). Luǵe u neluǵe. Skopje: Kočo Racin.] 
